Bangladesh J. Bot. 43(3): 331-335, 2014 (December)

\title{
ANTIOXIDANT AND ACETYLCHOLINESTERASE ACTIVITIES OF THREE SPECIES OF THE FAMILY LAMIACEAE
}

\author{
CT SADAShiva*, Y NaIdoo, JR NaIdoo, B KalichaRAN ANd G NaIDOo
}

School of Life Sciences, University of KwaZulu-Natal, Durban, South Africa-4000

Key words: Lamiaceae, Antioxidant activity, Acetylcholinesterase inhibition

\begin{abstract}
Antioxidant and acetylcholinesterase inhibitory activity of the three species namely, Endostemon obtusifolius (E. Mey. ex benth.) N. E. Br, Plectranthus zuluensis (T. Cooke) and Tetradenia riparia (Hochst.) Codd. were evaluated. Maximum antioxidant activity was exhibited by E. obtusifolius $\left(\mathrm{IC}_{50} 130 \mu \mathrm{g} / \mathrm{ml}\right)$ followed by T. riparia $\left(\mathrm{IC}_{50} 142 \mu \mathrm{g} / \mathrm{ml}\right)$ and $P$. zuluensis $\left(\mathrm{IC}_{50} 169 \mu \mathrm{g} / \mathrm{ml}\right)$. Acetylcholinesterase inhibition (AChEI) was highest in P. zuluensis $\left(\mathrm{IC}_{50} 290 \mu \mathrm{g} / \mathrm{ml}\right.$ ) followed by E. obtusifolius $\left(\mathrm{IC}_{50} 470 \mu \mathrm{g} / \mathrm{ml}\right.$ ) and T. riparia $\left(\mathrm{IC}_{50} 750 \mu \mathrm{g} / \mathrm{ml}\right)$. The results suggest that these three species possess natural antioxidants and acetylcholinesterase inhibitors, which may be beneficial for the treatment of Alzheimer's disease, that require high concentration of these compounds.
\end{abstract}

\section{Introduction}

In the symptomatic treatment of Alzheimer's disease (AD), enhanced cholinergic activity is achieved when the key enzyme responsible for ACh hydrolysis, acetylcholinesterase (AChE), is inhibited (Adewusi et al. 2011). Acetylcholine inhibitors (AChEIs) should function by preventing acetylcholine hydrolysis, thereby restoring ACh levels at the synapse (Giacobini 1998, Krall et al. 1999). Presently, AChE inhibitors cause adverse side effects therefore the drug discovery has now been directed to alternative AChE inhibitors from natural sources (Adewusi et al. 2011).

Oxidative stress, triggered by reactive oxygen species (ROS), is regarded as one of the earliest occurrences in AD patients. Currently, there is increased interest in antioxidants from plants to prevent oxidative damage and attenuate the effects of neurodegenerative disorders (Fusco et al. 2007, Amoo et al. 2012).

Studies indicate that decoctions of the leaves of Plectranthus barbatus contain rosmarinic acid, which has pronounced acetylcholinesterase and antioxidant activity (Fale et al. 2009). However, there is no record of the activity of Plectranthus zuluensis and Endostemon obtusifolius extracts. Decoctions of Tetradenia riparia have been widely utilized in traditional medicine, but its' cholinergic and antioxidant effect is yet to be investigated (Gairola et al. 2009). Plants in the family Lamiaceae are regarded as having great antioxidant potential and play a significant role in the protection against free radicals (Dorman et al. 2004, Erdemoglu et al. 2006, Orhan et al. 2007).

In this study the ethanolic extracts of three species of the Lamiaceae: E. obtusifolius, $P$. zuluensis and T. riparia were evaluated for their antioxidant and acetylcholinesterase activity.

\section{Materials and Methods}

P. zuluensis (Coll by R.G. Strey 7350000), E. obtusifolius (Coll by C.J. Ward 7345010) and T. riparia (Coll by C.J. Ward 7357a) were collected in Durban, KwaZulu-Natal during March 2011. Voucher specimens for all these plants were prepared and deposited at the Ward Herbarium, School of Life Sciences, University of KwaZulu-Natal, Durban, South Africa.

*Author for correspondence: $<$ sada1hassan@gmail.com>. 
Leaves from the three species were air dried at room temperature and then milled to powder form. The leaf powder $(250 \mathrm{~g})$ was extracted using a Soxhlet apparatus with ethanol. The resultant extracts were filtered and concentrated to dryness under reduced pressure in a rotary evaporator and stored at $4^{\circ} \mathrm{C}$ for further use.

The free radical scavenging activity of the crude extracts was determined by the 2,2diphenylpicrylhydrazyl (DPPH) assay described by Blois (1958) with slight modification. A 0.1 $\mathrm{mM}$ solution of DPPH in methanol was prepared and $4 \mathrm{ml}$ of this solution were added to $1 \mathrm{ml}$ of sample solution in methanol at different concentrations. All the assays were carried out in triplicate. The absorbance was read at $510 \mathrm{~nm}$. Percentage DPPH scavenging activity was determined as follows:

DPPH scavenging activity $(\%)=\left(\mathrm{A}_{0}-\mathrm{A}_{1}\right) / \mathrm{A}_{0} \times 100$

where $A_{0}$ is absorbance of standard DPPH solution only and $A_{1}$ is the absorbance of the reaction mixture or standard antioxidant.

A male Wister rat (150 g) was sacrificed by cervical dislocation; the brain was immediately excised and homogenized with cold $0.1 \mathrm{mM}$ sodium phosphate buffer $(\mathrm{pH}$ 7.0). The homogenate was stored at $-80^{\circ} \mathrm{C}$. Acetylcholinesterase inhibitory activity was measured following the method of Ellman et al. (1961). The percentage of AChE inhibition was determined with the help of the following equation:

Percentage inhibition $=\frac{\text { Control }- \text { Extract } \times 100}{\text { Control }}$

The total phenolics content was determined by the Folin-Ciocalteu assay (Singleton et al. 1965). Absorbance was determined at $550 \mathrm{~nm}$ with an UV-Visible spectrophotometer. Different gallic acid standard solutions $(20,40,60,80$ and $100 \mu \mathrm{g} / \mathrm{ml})$ were used for obtaining a standard curve (Singleton et al. 1965). Total phenolic content was expressed as $\mathrm{mg}$ of gallic acid equivalents (GAE) per gram of extract.

Total flavonoid content was measured by the aluminum chloride colorimetric assay (Zhishen et al. 1999). The solution was mixed and the absorbance measured against the blank at $510 \mathrm{~nm}$. The total flavonoid content was expressed as mg quercetin equivalents $(\mathrm{QE})$.

\section{Results and Discussion}

The antioxidant and acetylcholinesterase inhibitory activities of three species of Lamiaceae were evaluated in this study. Disturbance and insufficient cholinergic functions are identified among the pathological features of central nervous system disorders of the test rats. The most important changes observed in the brain are a decrease in cortical levels of the neurotransmitter acetylcholine. Inhibition of acetylcholinesterase activity, therefore, can restore levels of acetylcholine in the brain. The ethanolic extracts of E. obtusifolius, P. zuluensis and T. riparia (Table 1) showed good antioxidant and acetyl cholinesterase inhibitory activities. Acetyl cholinesterase inhibition was highest in $P$. zuluensis $\left(\mathrm{IC}_{50} 290 \mu \mathrm{g} / \mathrm{ml}\right)$ followed by E. obtusifolius $\left(\mathrm{IC}_{50} 470 \mu \mathrm{g} / \mathrm{ml}\right)$ and $T$. riparia $\left(\mathrm{IC}_{50} 750 \mu \mathrm{g} / \mathrm{ml}\right)$. Plants have traditionally been used to enhance cognitive function and to alleviate other symptoms associated with Alzheimer's disease (Howes and Houghton 2003). Similar species in Lamiaceae, such as Salvia, has been traditionally used in European folk medicine to improve memory (Adewusi et al. 2011). The degeneration of neurons by oxidative stress is a significant symptom at the onset of Alzheimer's disease. Therefore, the ability to scavenge free radicals is an important mechanism to treat patients suffering from degenerative diseases. The hydrogen donating capacity of the polyphenolic compounds is 
responsible for inhibition of free radicals. The potency of the extracts to scavenge radicals is inversely proportional to the inhibitory concentration. Maximum antioxidant activity was exhibited by E. obtusifolius $\left(\mathrm{IC}_{50} 130 \mu \mathrm{g} / \mathrm{ml}\right)$, followed by T. riparia $\left(\mathrm{IC}_{50} 142 \mu \mathrm{g} / \mathrm{ml}\right)$ and $P$. zuluensis, $\left(\mathrm{IC}_{50} 169 \mu \mathrm{g} / \mathrm{ml}\right.$ ), compared to standard BHA (Butylated hydroxyanisole) in the DPPH assay (Table 1). The efficacy of the antioxidant potential of the above extracts is affected by many factors: the part of the plant analysed, as well as time of harvesting, climatic conditions, storage and processing of the plant material (Jayachitra and Krithiga 2012). Further research needs to be conducted to elucidate the precise compounds in the ethanolic extract that could be responsible for the relative DPPH activities.

Studies have shown that antioxidant activity correlated strongly to aromatic, phenolic and flavonoid contents since these compounds can undergo redox reactions and therefore scavenge free radicals (Adewusi et al. 2011, Ghimire et al. 2011). Phenolic compounds such as gallotannins, condensed tannins and flavonoids contribute directly to the antioxidant activity of plant extracts (Proestos et al. 2006). The total phenolic content was least in E. obtusifolius (15.1 $\mu \mathrm{g})$, intermediate in P. zuluensis $(17.5 \mu \mathrm{g})$ and greatest in T. riparia $(26.2 \mu \mathrm{g})$ (Fig. 1). Since any phenolic compound (including aromatic amines), ascorbic acid and sugar reduce the FolinCiocalteu reagent; over-estimation of total phenolic content by this method could have affected the results of this assay (Siow and Hui 2013). Consequently, the high phenolic content of T. riparia resulted in a relatively intermediate antioxidant activity, compared to E. obtusifolius and $P$. zuluensis. Similarly, a low antioxidant activity (Table 1 ) was exhibited by P. zuluensis extracts, although there is an intermediate concentration of total phenolic content (Fig. 1). These results suggest that there may be other molecules responsible for conferring antioxidant activity in these species (Ghimire et al. 2011). Other classes of compounds that may have free radical scavenging capabilities, such as alkaloids, are currently used to treat Alzheimer's disease (Adewusi et al. 2011, Dell'Acqua 2013).

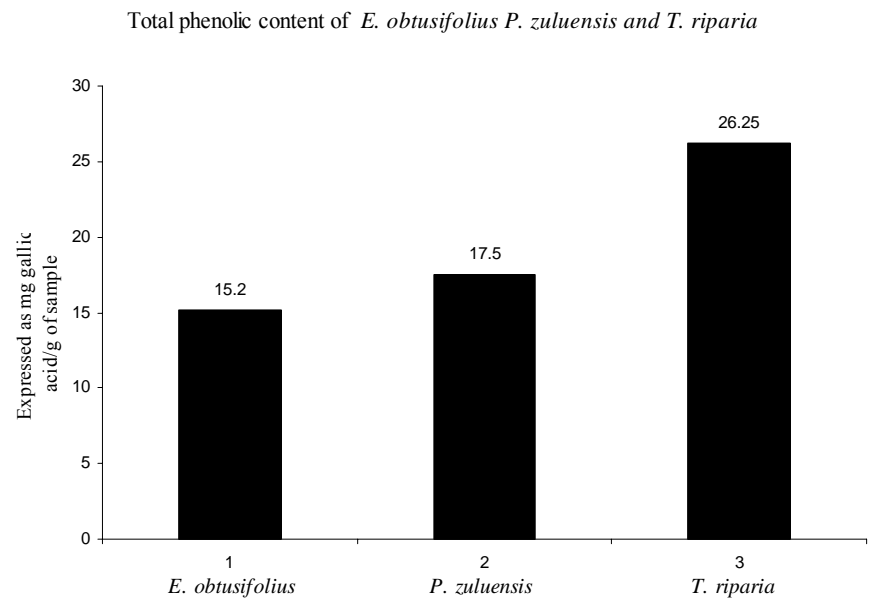

Fig. 1. Mean total phenolic content expressed as gallic acid equivalent of ethanolic leaf extracts of E. obtusifolius $P$. zuluensis and T. riparia.

The flavonoid content was greatest in E. obtusifolius $(7.0 \mu \mathrm{g})$, intermediate in T. riparia ( 0.6 $\mu \mathrm{g})$ and least in $P$. zuluensis $(0.42 \mu \mathrm{g})$ (Fig. 2). The high flavonoid content is possibly responsible for the high antioxidant activity in E. obtusifolius (Table 1). 
Total flavonoid content of $E$. obtusifolius $P$. zuluensis and T. riparia

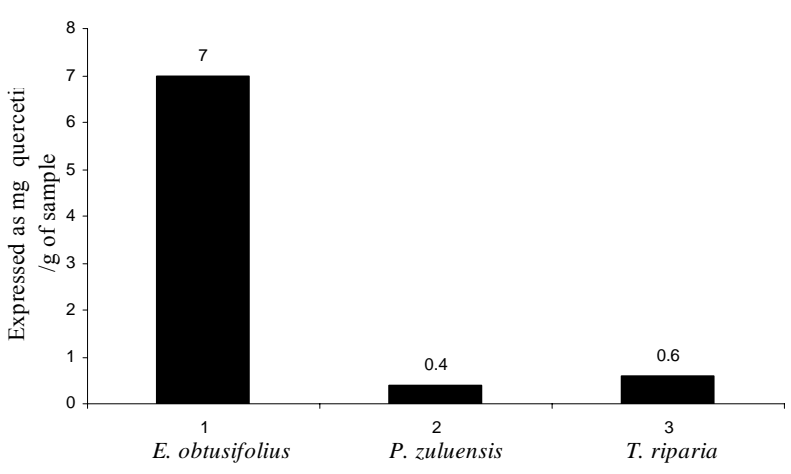

Fig. 2. Mean total flavonoid content expressed as quercetin equivalent of ethanolic leaf extracts of E. obtusifolius P. zuluensis and T. riparia.

Table 1. DPPH free radical scavenging activity and AChE inhibition of ethanolic leaf extracts of $E$. obtusifolius, P. zuluensis and T. ripari using BHA and neostigmine as standards.

\begin{tabular}{lcc}
\hline `Extracts & $\begin{array}{c}\mathrm{DPPH} \\
\mathrm{IC}_{50} \mu \mathrm{g} / \mathrm{ml}\end{array}$ & $\begin{array}{c}\text { AChE inhibition } \\
\mathrm{IC}_{50} \mu \mathrm{g} / \mathrm{ml}\end{array}$ \\
\hline E. obtusifolius & 130 & 470 \\
P. zuluensis & 169 & 290 \\
T. riparia & 142 & 750 \\
Neostigmine & - & 37.5 \\
BHA & 10 & - \\
\hline
\end{tabular}

Plant extracts used in dementia therapy vary according to culture and tradition. Several phytoconstituents can be exploited for their antioxidant and anti cholinesterase activities based on their use in traditional medicines. The extracts from these three plant species exhibited good antioxidant and acetyl cholinesterase inhibition. The data suggest that these species could be used as natural sources of antioxidant and acetyl cholinesterase inhibitors, and could possibly be used in the treatment of Alzheimer's disease. However, their potential beneficial effects and efficacy in humans require further clinical research.

\section{Acknowledgement}

This work was supported by the National Research Foundation, Centre for Medicinal Plants Research, Kerala, India and the University of KwaZulu-Natal.

\section{References}

Adewusi EA, Moodley N and Steenkamp V 2011. Antioxidant and acetylcholinesterase inhibitory activity of selected southern African medicinal plants. South African J. Bot. 77: 638-644.

Amoo SO, Aremu AO, Moyo M and Van Staden J 2012. Antioxidant and acetylcholinesterase-inhibitory properties of long-term stored medicinal plants. BMC. Complemen. Alternat. Med. 12: 1-9.

Benzi G and Moretti A. 1998. Is there a rationale for the use of acetylcholinesterase inhibitors in the therapy of Alzheimer's disease? European J. Pharmacol. 346: 1-13. 
Blois MS. 1958. Antioxidant determinations by the use of a stable free radical. Nature. 181: 1199-1200.

Dell Acqua S. 2013. Plant-derived acetylcholinesterase inhibitory alkaloids for the treatment of Alzheimer's disease. Botanics: Targets and Therapy 3: 19-28.

Dorman HJD, Bachmayer O, Kosar M and Hiltunen R. 2004. Antioxidant properties of aqueous extracts from selected Lamiaceae species grown in Turkey. J. Agril. and Food Chem. 52: 762-770.

Ellman GL, Courtney KD Andress V Jr, and Eartherstone RM. 1961. A new and rapid colorimetric determination of acetylcholinesterase activity. Biochem. Pharmacol. 7: 88-95.

Erdemoglu N, Turan NN, Cakici I, Sener B, and Aydin A. 2006. Antioxidant activities of some Lamiaceae plant extracts. Phytotherapy Res. 20: 9-13.

Falé PL, Borges C, Madeira PJA, Ascensão L, Araújo MEM, Florêncio, MH and Serralheiro MLM 2009. Rosmarinic acid, scutellarein 4'-methyl ether 7-O-glucuronide and (16S)-coleon E are the main compounds responsible for the antiacetylcholinesterase and antioxidant activity in herbal tea of Plectranthus barbatus ("falso boldo"). Food Chem. 114: 798-805.

Fusco D, Colloca G, Lo Monaco MR and Cesari M. 2007. Effects of antioxidant supplementation on the ageing process. Clinical Interventions in Aging. 2: 377-387.

Gairola S, Naidoo Y, Bhatt A and Nicholas A 2009. An investigation of the foliar trichomes of Tetradenia riparia (Hochst.) Codd (Lamiaceae). An important medicinal plant of Southern Africa. Flora 204: 325330.

Ghimere BK, Seong ES, Kim EH, Ghimeray AK, Yu GY, Ghimere BK and Chung MA 2011. A comparative evaluation of the antioxidant activity of some medicinal plants popularly used in Nepal. J. Med. Plants Res. 5(10): 1884-1891.

Giacobini E 1998. Invited review: cholinesterase inhibitors for Alzheimer's disease therapy: from tacrine to future applications. Neurochem. Internat. 32: 413-419.

Howes MJR and Houghton PJ 2003. Plants used in Chinese and Indian traditional medicine for improvement of memory and cognitive function. Pharmacol. Biochem. Behav. 75(3): 513-27.

Jayachitra A. and Krithiga N 2012. Study on antioxidant property in selected medicinal plant extracts. Intl. J. Med. Arom. Plants 2(3): 495-500.

Kasa P, Rakonczay Z and Gulya K 1997. The cholinergic system in Alzheimer's disease. Progress in Neurobiology. 52(6): 511-535.

Krall WJ, Sramek JJ and Cutler NR 1999. Cholinesterase inhibitors a therapeutic strategy for Alzheimer's disease. Ann Pharmacother. 33: 441-450.

Orhan I, Kartal M, Naz Q, Ejaz A, Yilmaz G, Kan Y, Konuklugil B, Sener B and Choudhary MI 2007. Antioxidant and anticholinesterase evaluation of selected Turkish Salvia species. Food Chem. 103: 1247-1254.

Proestos C, Boziaris IS Nychas GJE and Komaitis M 2006. Analysis of flavonoids and phenolic acids in Greek aromatic plants: Investigation of their antioxidant capacity and antimicrobial activity. Food Chem. 95(4): 664-671.

Singleton VL, Rossji Jr and. Joseph A 1965. Colorimetry of total phenolics with phosphomolibdicphosphotungstic acid reagents. Am. J. Enol. Vitic. 16: 144-158.

Siow LF and Hui YH 2013. Comparison on the antioxidant properties of fresh and convection oven-dried guava (Psidium guajava L.). Intl. Food Res. J. 20(2): 639-644.

Zhishen J, Mengcheng T and Jianming W 1999. Determination of flavoid content in Mulberry and their scavenging effect on superoxide radicals. Food Chem. 64: 555-559.

(Manuscript received on 11 June, 2013; revised on 10 April, 2014) 